\title{
Nonspecific Impact of Reflective Mind on Implicit Evaluative Processes: Effects of Experimental Manipulations and Selected Dispositional Factors
}

\author{
Maria Jarymowicz * and Anna Szuster \\ Faculty of Psychology, University of Warsaw, Warsaw, Poland
}

Keywords: implicit affective priming, implicit self-reference effect, primary affect's independence effect, self-distinctness, evaluative heterogeneity, taking perspective of others

There is a growing interest in the phenomena of mind duality, one of the most intriguing properties of human nature. A review of classic texts (Maslow, 1954; Reykowski, 1975; Schneider and Shiffrin, 1977; Epstein, 1983) as well as more recent works (Gawronski and Bodenhausen, 2006; Clore and Huntsinger, 2007; Kahneman, 2011; Evans and Stanovich, 2013; Gawronski and Creighton, 2013; Sherman et al., 2014; Strack and Deutsch, 2014) shows that the authors refer to the distinctions between mental codes (affective vs. intellectual), cognitive and evaluative processes (associative vs. propositional), levels of consciousness, and regulatory systems (automatic vs. controlled). Advances

OPEN ACCESS

Edited by:

Lionel Brunel,

Paul Valéry University, Montpellier III,

France

Reviewed by:

Cristiano Crescentini,

University of Udine, Italy

*Correspondence:

Maria Jarymowicz

mariaj@psych.uw.edu.p

Specialty section:

This article was submitted to

Cognition,

a section of the journal

Frontiers in Psychology

Received: 19 April 2017 Accepted: 28 August 2017 Published: 11 September 2017

Citation: Jarymowicz M and Szuster A (2017) Nonspecific Impact of Reflective Mind

on Implicit Evaluative Processes:

Effects of Experimental Manipulations and Selected Dispositional Factors.

Front. Psychol. 8:1572.

doi: 10.3389/fpsyg.2017.01572 in neurobiological research help to understand interrelations between diverse brain structures and regulative rules.

The alliance of psychology with neuroscience has become a standard in studies on emotions understood as evaluative processes (Ekman and Davidson, 1994; LeDoux, 1996, 2012; Oatley and Jenkins, 1996; Panksepp, 1998; Liberman, 2003; Sander and Scherer, 2009; Linquist et al., 2012; Imbir et al., 2015). The research conducted in our laboratory aims to differentiate between two evaluative systems: primary/automatic and reflective (Jarymowicz, 2008; Jarymowicz and Imbir, 2015). On the basis of the neurobiological and psychological models we assume that interactions between these two systems are reciprocal. The purpose of this opinion article is to present some empirical arguments related to the nonspecific impact of the reflective system on the automatic one.

\section{BASIC CHARACTERISTICS OF TWO EVALUATIVE SYSTEMS: PRIMARY/AUTOMATIC AND REFLECTIVE}

The theoretical framework of our studies is based mainly on Zajonc's idea of the primacy of affect (Zajonc, 1980, 1984) and LeDoux's (1996) model of different roads of stimuli to the amygdala ("the emotional computer"; Sander et al., 2003) - the subcortical and the cortical ones. The research program attempts to define the specificity of the two diverse evaluative systems, their functions, and their reciprocal relationships (Jarymowicz, 2008, 2016; Jarymowicz and Imbir, 2015).

Our studies quoted below concern the primary automatic system generating evaluations based on subcortical processes (LeDoux, 1996, 2012) and implicit cognition leading to implicit appraisals (Sander and Scherer, 2009). Such affective reactions to stimuli occur in a mindless manner. All their attributes_origin, content, and effects (Gawronski et al., 2006)—can be totally implicit, that is introspectively unidentified (Greenwald and Banaji, 1995). Since primary affects are diffusive (Zajonc, 1980), they often influence explicit judgments concerning diverse objects, unrelated to unconscious stimuli (Murphy and Zajonc, 1993). 
The reflective evaluative system, based on deliberate thinking, requires effort and is time- and energy-consuming. Moreover, evaluations can't be made without referring to cognitive, verbalized evaluative standards (Reykowski, 1989) which serve as mental bases for the object's appraisal in terms (often abstract ones) of good and evil. The evaluative processes are developed as a result of comparison between the actual, real circumstances and the conceptual, verbalized standards. Appraisals are made as a consequence of: (1) search for appraisals' premises, (2) piecemeal analyses of the object's properties, and (3) heterogeneous evaluations which, finally, reduce certainty and extremity of judgments (Jarymowicz, 2016).

Numerous data show a nonspecific influence of implicit affective stimuli on explicit judgments and behavior (e.g., Chen and Bargh, 1997; Berridge and Winkielman, 2003; Ohme, 2007). The explanations are based on the data showing that primary diffusive affects have an impact on subsequent explicit appraisals. Thus, verbalized judgments can be dominated by previous, even unconscious affective reactions to unrelated stimuli. Apparently this type of influence leads to numerous negative consequences. Hence, an important question arises: which processes may reduce the primary, nonspecific affective influence on thinking and judgments?

\section{THE MAIN ASSUMPTION: THE REFLECTIVE SYSTEM CHANGES THE RULES OF EVALUATIVE PROCESSES}

Researchers are familiar with the spectacular case of Phineas Gage (Damasio, 1994), who, having suffered injury to the frontal lobes, lost the ability to control his own impulsive reactions. Today there is no doubt that the prefrontal brain modifies the processes evoked on the lower levels of the central nervous system (Gazzaniga, 2012). This implies, in psychological terms, that the impact of primary affective reactions (for instance, negative affect due to expression of subliminally exposed face) on judgments concerning unrelated objects (like Chinese signs) can be limited. According to our hypothesis, the reduction of primary affects' influence can be due not only to (1) a voluntary, reflective control over evaluative processes (when a subject is motivated to weight her/his own words), but also to (2) a nonspecific activation of the reflective system, which is connected with different rules of evaluation.

The results of gathered data show a specific influence of the subject's beliefs on her/his automatic reactions to implicit stimuli. This means that thinking and reasoning have an impact not only on the explicit knowledge and memory, but also on the implicit information processing (Uleman and Bargh, 1989; Underwood, 1996; Chen and Bargh, 1997; Holyoak and Morrison, 2005). However, can a nonspecific influence of the reflective evaluative system on the automatic evaluative system actually be evidenced?

There are reasons to posit that development of the reflective mind changes the rules of the entire mind's functioning. In particular, it can be assumed that the development of the reflective evaluative system leads to a habitual disposition to seek verbalized premises of one's own judgments. Also, its habitual character can result in relative independence from the influence of irrelevant affective processes on evaluative thinking. A series of our studies yielded some empirical evidence supporting these assumptions.

\section{METHODOLOGY: THE AFFECTIVE IMPLICIT PRIMING PARADIGMS AND MEASUREMENTS OF THEIR EFFECTS}

The implicit priming paradigm constructed by Murphy and Zajonc (1993) was applied to all the studies mentioned below, although with some modifications. In the original version, participants were requested to intuitively evaluate unknown Chinese ideograms-allegedly "symbolizing human traits"-in terms of their negativity vs. positivity. Each sign was primed with a neutral or affective subliminal stimulus (exposed for 12 $\mathrm{ms}$ ), i.e., a photograph of a face showing a neutral, positive, or negative expression. In some of our experiments, participants had to intuitively evaluate the extent to which a given ideogram "represents a trait" characteristic to the self-to measure the socalled Implicit Self-Reference Effect (Błaszczak and Imbir, 2012).

The original data analyses aimed at comparing the effects exerted by the type of experimental conditions (neutral $\times$ negative $\times$ positive priming) on the explicit evaluation of a neutral ideogram. This paradigm allows to show the impact of implicit affective priming on neutral stimuli evaluations (Ohme, 2007; Karwowska and Kobylińska, 2014).

An important modification of the affective priming impact index was introduced by Karwowska (2001), in order to differentiate between the participants who were more or less resistant to the influence of implicit affective stimuli. A difference between explicit appraisals made after exposure of negative or positive priming vs. the ones generated in control conditions (priming with a neutral stimulus) was calculated for each individual. The differences between appraisals following the affective vs. neutral priming show that explicit appraisals of a neutral stimulus (Chinese ideogram) are more or less neutral, and as such, relatively dependent upon/independent from the implicit affective priming.

\section{NONSPECIFIC ACTIVATION OF THE REFLECTIVE SYSTEM AND REGISTRATION OF AUTOMATIC REACTIONS TO IMPLICIT STIMULI}

In a series of studies, Karwowska (Karwowska and Kobylińska, 2014) applied the implicit affective priming paradigm. However, in the first stage of each study the author requested that participants present arguments concerning some social problems beforehand. For instance, they had to indicate positive and negative attributes of patriotism, or to enumerate arguments for and against acceleration of adoption procedures for children. The control groups dealt with a simple cognitive task: they had to compare pairs of 
numbers and say, in each case, if both were identical or different.

Next, the participants were invited to "a study on intuition." They were asked to estimate the degree to which a trait (allegedly) symbolized by a given Chinese ideogram was negative or positive. Each ideogram was primed with suboptimal exposition of a photo of a face with neutral, negative, or positive expression. A repeated effect was found: the participants who were subject to a prior, deliberative thinking stimulation estimated neutral ideograms as significantly more neutral than the participants in the control conditions. We called this effect the "Primary Affect's Independence Effect" (PAI).

The PAI effect was measured in some studies aimed at identifying dispositional factors determining resistance to diffusive irrelevant affective influence on judgments and behavior (Jarymowicz, 2008). It was assumed that the relationships between automatic and reflective regulative systems are applicable not only to the conditions in which uncontrolled affective and controlled reflective processes are simultaneously stimulated. Further, it was presumed that reflective mind development leads to a kind of habitual readiness to seek evident evaluative judgment premises rather than guess what a given, unknown object or reality condition means. Based on the latter assumption, correlations between some selected dispositional factors and the PAI effect were predicted.

\section{DISPOSITIONAL FACTORS AS POSSIBLE CORRELATES OF RESISTANCE TO THE IMPLICIT AFFECT INFLUENCE ON JUDGMENTS}

The studies' project was aimed to include some dispositional determinants of the PAI effect. As it was assumed that some dispositions have to be connected with reflective mind development, our interest fell on the determinants supposedly developed on the basis of reflective thinking. Three determinants had been chosen-all selected from our earlier personality research. (1) The first one-the Self-Others Schemata Distinctness-concerns the difference between prototypical traits ascribed (independently) by a subject to the self vs. to other people (Jarymowicz, 1987, 1991; Jarymowicz and Szuster, 2016). (2) The second one-Evaluative Heterogeneity-refers to the ability to perceive negative as well as positive attributes of the same object (Jarymowicz, 2016). (3) The third one-Exocentric Altruism - is related to centration on others and understanding the perspective of other people (Szuster, 2005; Szuster and Rutkowska, 2008).

All these variables are measured in a simple manner. The selfothers schemata distinctness variable is measured by comparing the traits consecutively indicated by the subject as the most important for characterizing (a) other people and (b) the self. The evaluative heterogeneity variable is measured by the proportion of negative and positive attributes ascribed by the subject to a given object. The exocentric altruism is measured by way of manifesting the subject centration on other persons' states.

\section{CORRELATIVE STUDIES: DISPOSITIONAL FACTORS AND REACTIONS TO THE IMPLICIT AFFECTIVE STIMULI}

The hypotheses predicted that the degree of influence of implicit affective priming on estimation of Chinese ideograms will depend on the level of each of the dispositional variables. The same data pattern was found in all the studies (Jarymowicz, 2008): the higher the indices of self-distinctness, evaluative heterogeneity, or exocentric altruism, the more neutral the explicit estimations of the neutral Chinese ideograms (allegedly human traits) implicitly primed with photos of faces with negative or positive expressions.

In another study (Jarymowicz, 2008), self-distinctness and the Implicit Self-Reference Effect were measured. The result was consistent with the above-mentioned research: the higher the indices of self-distinctness, the lower the degree of reference of neutral, unknown Chinese ideograms primed with photos of unknown faces to the self.

Thus, all the gathered data indicate that self-others schemata distinctness, evaluative heterogeneity, and exocentric altruismas measurements of dispositional variables-correlate positively with a kind of resistance to the influence of the implicit affective priming on one's own judgments.

\section{CONCLUSIONS}

Numerous arguments allow to differentiate between the reflective evaluative system connected with specific evaluative rules and the system evoking automatic affective reactions. The empirical studies show that implicit affective stimuli can have a nonspecific impact on explicit judgments. On the other side, the data mentioned above suggest that resistance to implicit stimulation can be caused by the nonspecific impact of the reflective system on the automatic one. The results were similar in the two types of studies mentioned: those in which deliberative thinking stimulation was applied, and those in which some reflective dispositions were measured.

In more general terms, it can be assumed that reflective system development leads to changes in the system of principles controlling automatically evoked affects. In particular, the data suggest that the reflective evaluative system may inhibit influence of primary affective reactions on judgments.

\section{AUTHOR CONTRIBUTIONS}

MJ: Substantial contributions to the general assumptions, data analyses, and interpretations; Draft and the final version of the Opinion Article (with the common approval of all parts of texts by both authors). AS: Contribution to the part of design of studies on the exocentric altruizm, data analyses, and interpretations; Draft and the final version of the Opinion Article (with the common approval of all parts of texts by both authors). 


\section{REFERENCES}

Berridge, K. C., and Winkielman, P. (2003). What is unconscious emotion: the case of unconscious "liking". Cogn. Emot. 17, 181-211. doi: 10.1080/02699930302289

Błaszczak, W., and Imbir. K. (2012). Use of affective priming to measure implicit self-reference effect. Psychol. Rep. 111, 107-114. doi: 10.2466/07.21.24.PR0.111.4.107-114

Chen, M., and Bargh, J. A. (1997). Nonconscious behavioral confirmation processes: the self-fulfilling consequences of automatic stereotype activation. J. Exp. Soc. Psychol. 33, 541-560. doi: 10.1006/jesp.1997.1329

Clore, G. L., and Huntsinger, J. L. (2007). How emotions inform judgment and regulate thought. Trends Cogn. Sci., 11, 393-399. doi: 10.1016/j.tics.2007.08.005

Damasio, A. R. (1994). Descartes' Error. Emotion, Reason, and the Human Brain. New York, NY: Putman.

Ekman, P., and Davidson, R. J. (1994). The Nature of Emotions. Fundamental Questions. New York, NY: Oxford Un. Press.

Epstein, S. (1983). "The unconscious, the preconscious, and the self-concept," in Psychological Perspective on the Self, Vol. 2, eds J. Suls and A. G. Greenwald (Hillsdale, NJ: Erlbaum), 217-247.

Evans, J. S., and Stanovich, K. E. (2013). Dual-process theories of higher cognition advancing the debate. Perspect. Psychol. Sci. 8, 223-241. doi: $10.1177 / 1745691612460685$

Gawronski, B., and Bodenhausen, G. V. (2006). Associative and propositional processes in evaluation: an integrative review of implicit and explicit attitude change. Psychol. Bull. 132, 692-731. doi: 10.1037/0033-2909.132.5.692

Gawronski, B., and Creighton, L. A. (2013). "Dual-process theories," in The Oxford Handbook of Social Cognition, ed D. E. Carlston (NewYork, NY: Oxford Un. Press), 282-312. doi: 10.1093/oxfordhb/9780199730018.013.0014

Gawronski, B., Hofmann, W., and Wilbur, C. J. (2006). Consciousness and Cognition 15, 486-499. doi: 10.1016/j.concog.2005.11.007

Gazzaniga, M. S. (2012). Who's in Charge? Free Will and the Science of the Brain. New York, NY: Ecco/HarperCollins.

Greenwald, A. G., and Banaji, M. R. (1995). Implicit social cognition: attitudes, selfesteem and stereotypes. Psychol. Rev. 102, 4-27. doi: 10.1037/0033-295X.102.1.4

Holyoak, K. J., and Morrison, R. G. (eds.) (2005). The Cambridge Handbook of Thinking and Reasoning. NewYork, NY: Cambridge Un. Press.

Imbir, K., Jarymowicz, M., Spustek, T., Kuś, R., and Żgierewicz, J. (2015). Origin of emotion effects on ERP correlates of emotional word processing: the emotion duality approach. PLoS ONE 10:e0126129. doi: 10.1371/journal.pone.0126129

Jarymowicz, M. (1987). Perceiving One's Own Individuality. Warszawa: Wyd. UW.

Jarymowicz, M. (1991). Distinctivité Soi - Nous - Autres comme une base d'identité individuelle et sociale. Cahiers. Intern. Psychol. Soc. 9-10, 103-116.

Jarymowicz, M. (2008). Psychologiczne Podstawy Podmiotowości. Warszawa: Wyd. Naukowe PWN.

Jarymowicz, M. (2016). Affect and intellect in judgments: factors which determine level of the evaluative heterogeneity. Front. Psychol. 7:569. doi: 10.3389/fpsyg.2016.00569

Jarymowicz, M., and Imbir, K. (2015). Toward a human emotions taxonomy (based on their automatic vs. reflective origin). Emot. Rev. 7, 183-188. doi: $10.1177 / 1754073914555923$

Jarymowicz, M., and Szuster, A. (2016). Self-we-others schemata differentiation as a base for personal agency and social attitudes. Front. Psychol. 7:1227. doi: $10.3389 /$ fpsyg.2016.01227

Kahneman, D. (2011). Thinking, Fast and Slow. New York, NY: Farrar, Straus and Giroux.

Karwowska, D. (2001). "Wpływ utajonych bodźców afektywnych na ocenianie w warunkach koncentracji na wartościowaniu refleksyjnym," in Pomiędzy Afektem a Intelektem, ed M. Jarymowicz (Warszawa: Wyd. IP PAN), 191-199.

Karwowska, D., and Kobylińska, D. (2014). Exploring the effects of suboptimal affective priming: enhancement and minimization. Front. Psychol. 5:499. doi: $10.3389 /$ fpsyg.2014.00499
LeDoux, J. E. (1996). The Emotional Brain. New York, NY: Touchstone.

LeDoux, J. E. (2012). Rethinking the emotional brain. Neuron 73, 653-676. doi: 10.1016/j.neuron.2012.02.004

Liberman, M. D. (2003). "Reflexive and reflective judgment processes: a social cognitive neuroscience approach" in Social Judgments: Implicit and Explicit Processes, eds J. P. Forgas, K. D. Williams, and W. von Hippel (Cambridge: Cambridge Un. Press), 44-67.

Linquist, K. A., Wager, T. D., Kober, H., Bliss-Moreau, E., and Barret, L. F. (2012). The brain basis of emotion: a meta-analytic review. Behav. Brain Sci. 35, 121-143. doi: 10.1017/S0140525X11000446

Maslow, A. H. (1954). Motivation and Personality. New York, NY: Harper and Row. Publ.

Murphy, S. T., and Zajonc, R. B. (1993). Affect, cognition and awareness: affective priming with optimal and suboptimal stimulus exposure. J. Pers. Soc. Psychol. 64, 723-739. doi: 10.1037/0022-3514.64.5.723

Oatley, K., and Jenkins, J. M. (1996). Understanding Emotions. Oxford: Blackwell Publ.

Ohme, R. K. (2007). Nieuświadomiony Afekt. Gdańsk: GWP.

Panksepp, J. (1998). Affective Neuroscience. New York, NY: Oxford Un. Press.

Reykowski, J. (1975). "Osobowość jako centralny system regulacji i integracji czynności," in Psychologia. Podręcznik Akademicki, ed T. Tomaszewski (Warszawa: PWN), 762-825.

Reykowski, J. (1989). "Dimensions of development of moral values," in Social and Moral Values, eds J. Reykowski, N. Eisenberg, and E. Staub (Hillsdale, NJ: Erlbaum), 23-44.

Sander, D., Grafman, J., and Zalla, T. (2003). The human amygdala: an evolved system for relevance detection. Rev. Neurosci. 14, 303-316. doi: 10.1515/REVNEURO.2003.14.4.303

Sander, D., and Scherer, K. R. (eds.). (2009). The Oxford Companion to Emotion and the Affective Sciences. New York, NY: Oxford Un. Press.

Schneider, W., and Shiffrin, R. M. (1977). Controlled and automatic human information processing. Psychol. Rev. 69, 379-399.

Sherman, J. W., Gawronski, B., and Trope, Y. (eds.) (2014). Dual-Process Theories of the Social Mind. New York, NY: Guilford Press.

Strack, F., and Deutsch, R. (2014). "The reflective - impulsive model," in Dual-Process Theories of the Social Mind, eds. J. W. Sherman, B. Gawronski, and Y. Trope (NewYork, NY: Guilford Press), 92-104.

Szuster, A. (2005). W Poszukiwaniu źródeł i Uwarunkowań Ludzkiego Altruizmu. Warszawa: Wyd.IP PAN.

Szuster, A., and Rutkowska, D. (2008). "O mechanizmach endo- i egzocentrycznej motywacji prospołecznej” in O różnych Obliczach Altruizmu, eds D. Rutkowska and A. Szuster (Warszawa: Scholar), 157-164.

Uleman, J. S., and Bargh, J. A. (1989). Unintended Thought. New York, NY: Guilford Press.

Underwood, G. (ed.) (1996). Implicit Cognition. Oxford: Oxford Un. Press.

Zajonc, R. B. (1980). Feeling and thinking. Preferences need no inferences. Am. Psychol. 35, 151-175. doi: 10.1037/0003-066X.35. 2.151

Zajonc, R. B. (1984). On the primacy of affect. Am. Psychol. 39, 117-123. doi: 10.1037/0003-066X.39.2.117

Conflict of Interest Statement: The authors declare that the research was conducted in the absence of any commercial or financial relationships that could be construed as a potential conflict of interest.

Copyright (ㄷ 2017 Jarymowicz and Szuster. This is an open-access article distributed under the terms of the Creative Commons Attribution License (CC BY). The use, distribution or reproduction in other forums is permitted, provided the original author(s) or licensor are credited and that the original publication in this journal is cited, in accordance with accepted academic practice. No use, distribution or reproduction is permitted which does not comply with these terms. 